\title{
No way to run a superpower
}

The scientific community had low expectations for the Bush administration when it was first elected. The record since 2001 shows that these expectations were justified.

T rom its outset, the administration of President George W. Bush drew a line in the sand on several major science-related issues, including global warming (it opposed government action to cut greenhouse-gas emissions) and ballistic-missile defence (it would be deployed, and would work). Critics, including scientists, have been shut out from providing meaningful input on these issues.

More positively, from scientists' perspective, this administration's budgets have been reasonably supportive and the president has, on the whole, appointed competent officials to key positions. Over the past two-and-a-half years, however, there has been a steady accumulation of reported attempts by the Bush administration to distort scientific evidence or rig advisory panels for political purposes. With the Republican Congress ever compliant to the administration, few questions have been raised about these complaints and the administration has been under little pressure to justify its actions.

That's why this month's report by Henry Waxman (Democrat, California), the senior Democrat on the Government Reform Committee in the House of Representatives, should be welcomed. In a relatively comprehensive and succinct 33-page document, Waxman's staff have, at the very least, put together a cogent case for the prosecution (www.politicsandscience.org; see Nature 424, 715; 2003). "The Administration's political interference with science has led to misleading statements by the President, inaccurate responses to Congress, altered web sites, suppressed agency reports, erroneous international communications, and the gagging of scientists," it states.

Waxman has a good record in health and environmental issues, and his staff's detailed criticisms of administration actions deserve to be taken seriously. But the White House response has been characteristically curt, deriding Waxman as a biased observer who was "playing politics". The rest of the administration's defence has been unintentionally self-revealing. "This administration looks at the facts, and reviews the best available science based on what's right for the American people,"
White House spokesman Scott McClellan told The New York Times.

Administration officials have offered no point-by-point repudiation of the allegations in the report, either when they were first made or when Waxman repeated them. If they had done so, many of the allegations might have been laid to rest. There has been some political interference in agencies' decisions, and decisions have been made on the basis of political considerations rather than science. But Waxman does not establish that that this has been much more pervasive than under previous administrations.

It isn't by the prevalence of junior-level dabbling that this administration should be judged. Two things stand out in its track record on science: its handling of a few key scientific issues; and its culture of iron-clad corporate discipline, which has come into conflict with relative independence customarily enjoyed by US scientific agencies. Waxman is on his strongest ground when he attacks the impact of the latter on such nominally independent agencies as the Environmental Protection Agency (EPA) and the Centers for Disease Control and Prevention. The premature departure of Christine Todd Whitman, a moderate Republican, from the administrator's position in the EPA speaks to the curtailment of that independence under Bush.

On this occasion, Waxman doesn't dwell on the Bush administration's reluctance to engage. In 2001, the administration asked the National Academy of Sciences for an assessment of global warming that it hoped would cast aspersions on the findings of the Intergovernmental Panel on Climate Change. From the administration's point of view, the academy failed to come up with the goods, and it hasn't repeated the exercise.

On major policy issues such as global warming, ballistic-missile defence and stem-cell research, Bush committed early on to an ideologically driven approach, and has stuck to it. In an age when science pervades so many aspects of government, this is a remarkable, and remarkably ill-judged, approach to setting policy.

\section{Goodbye, flat biology?}

\section{Seductive higher dimensions could consign glass dishes to history.}

W hen the otherwise obscure Julius Richard Petri, one-time assistant to pioneering bacteriologist Robert Koch, published in 1887 his methodology for growing colonies of bacteria on a base of gelatin in flat glass dishes, he seemingly guaranteed his own immortality. The development of bacteriology and microbiology — not to mention molecular biology — would have been unthinkable without the modest Petri dish, which remains a fundamental laboratory item today.

But biologists starting to explore the merits of culturing cells in three dimensions (3-D), rather than in the flat-dish's two dimensions, have been stunned by the difference that it makes to the way the cells behave, which is much closer to their behaviour in vivo (see page 870). Cancer biologists find that cells can be made to switch between malignant and non-malignant states in 3-D but not in 2-D. Developmental biologists find that their cells proliferate much faster in 3-D than in 2-D. The fat lady is not yet singing for the Petri dish, but she is certainly clearing her throat.

Culturing cells in 3-D is neither convenient nor cheap, however, and won't necessarily help to answer simple biochemical questions. But it is only a matter of time before 3-D techniques become standardized and cost-benefit ratios become irresistible in many areas of biology. Those who have experienced the merits of 3-D first-hand are convinced that any biologist studying a system where the microstructure environment is important in vivo - such as neurobiology, atherosclerosis or diabetes - will have to bid the Petri dish farewell in the next decade if they are to continue being taken seriously.

Awareness of the potential of 3-D tissue culture among scientists is far too low. But the benefits of the technique are so self-evident that little marketing will be needed to persuade the uninitiated to move up a dimension, just as soon as the issues of convenience are resolved. 